\title{
INFLUENCE OF ACID MINE WATER ON THE DIVERSITY AND METABOLITE SHIFT OF MICROBIAL POPULATIONS OF THE RHIZOSPHERE OF COMMON REED (PHRAGMITES AUSTRALIS)
}

\author{
MANG, K. C. - NTUSHELO, K.* \\ Department of Agriculture and Animal Health, University of South Africa, South Africa \\ (e-mail: kaluchimdimang@yahoo.com; phone: +27-(0)-748-366-063) \\ *Corresponding author \\ e-mail:ntushk@unisa.ac.za; phone:+27-(0)-789-027-944 \\ (Received $19^{\text {th }}$ Jun 2019; accepted $25^{\text {th }}$ Oct 2019)
}

\begin{abstract}
Common reed (Phragmites australis (Cav.) Trin. ex Steud.) grows widely in various acid mine water bodies and remediates these polluted sites. There exists only a paucity of studies on the effect of acid mine water on microbial diversity and secondary metabolite compositions of the rhizosphere of the common reed. The aim of this study was therefore to determine the influence of acid mine drainage on the microbial diversity of the rhizosphere of the common reed as well as on its secondary metabolite composition. Two acid mine water bodies were selected for study and were compared with a normal water body. The acid mine status of the water bodies was confirmed by assessing a set of physicochemical properties, microbial diversity was measured using BIOLOG EcoPlates and secondary metabolite compositions were determined by nuclear magnetic resonance. Results showed that acid mine drainage reduces rhizosphere microbial diversity as well as influences secondary metabolite composition.
\end{abstract}

Keywords: rhizoremediation, microbes, bioremediation, Shannon index, BIOLOG EcoPlates

\section{Introduction}

Acid mine drainage (AMD) also known as acid rock drainage is a process that occurs as a result of the contact between oxygenated water and mineral pyrite which leads to the oxidation of the pyrite and the production of acids (Evangelou, 1995; Blowes et al., 2003). Areas affected by AMD are usually lost but there are various remediation technologies adopted by many countries to mitigate the impact of AMD, among them is the use of reeds such as Typha sp. and Phragmites sp. which can adsorb heavy metals. Phragmites australis (Cav.) Trin. ex Steud.) is a large perennial grass that is predominant in wetlands in the temperate and tropical regions of the world. The microbes associated with the rhizosphere of $P$. australis are believed to contribute to the remediation ability of the plant via the synthesis of metabolites which enhances the growth of plant and hyperaccumulation of the pollutants by both the plant and associated microbes (Bulgarelli et al., 2012; Kawasaki et al., 2016; Robertson-Albertyn et al., 2017; Pétriacq et al., 2017).

Rhizoremediation effectiveness is based on the complementary process between the plants and the microbes where plants pull contaminants into their rhizosphere and the microbes degrade them either in the rhizosphere or in the plant itself or both (Barac et al., 2004; Muratova et al., 2008). Phragmites australis employs this method of remediation (Scholes et al., 1999). However, very little is known about the rhizosphere microbial diversity and secondary metabolite profiles of $P$. australis in acid mine sites. This study is aimed at determining the influence of acid mine drainage on the diversity of rhizosphere microbes and the secondary metabolite profiles of $P$. australis. The effect of acid mine drainage on microbial diversity, in general, is understood and therefore the concern of the authors of this manuscript focused on the rhizosphere microbes due to their role in 
bioremediation and the uniqueness of their habitat. The understanding of the influence of acid mine water on the diversity of microbial populations in the rhizosphere of the bioremedial $P$. australis and the metabolite shift may prove to be vital knowledge for bioremediation processes and microbes adaptations in acid mine.

\section{Materials and Methods}

This study was undertaken to assess the effect of acid mine drainage on the microbial diversity and secondary metabolite shifts of rhizosphere soil of two acid mine sites (Wuinze 17 and Lan 3) and one non-acid mine site (Florida Lake) in the Gauteng province in South Africa which were all within a $17.7 \mathrm{Km}$ radius. Rhizosphere soil sampling was done on the edge of the water body where the plant roots are constantly submerged in water. In three field study regimes undertaken, water was also sampled to determine its physicochemical parameters to assess the extent of acid mine drainage. Acid mine water and contaminated soils are characterised by high electrical conductivity (EC), high total dissolved solutes (TDS), high salinity (Sa), and low $\mathrm{pH}$ which is why these parameters were measured to confirm acid mine contamination of the selected sites. The temperature was also measured to evaluate the temperature variation in the acid mine drainage sites and the non-acid mine drainage site. Following the sampling of the water, and soil, microbial diversity of the rhizosphere soil was assessed as well as secondary metabolite profiles of the rhizosphere soil.

\section{Study Area}

Lan 3 (S $26^{\circ} 07.820^{\prime}$, E $027^{\circ} 46.680^{\prime}$ and elevation of $1693 \mathrm{~m}$ ), a tailing dam of Mintails Mogale Gold Mine in Randfontein and Wuinze 17 (S 26 07.171', E 027 ${ }^{\circ} 43.305^{\prime}$ and elevation of $1670 \mathrm{~m}$ ), a tailing dam of Sibanye Gold Mine were the acid mine sampling sites in this study. Both sampling sites are located in Randfontein, Gauteng Province, South Africa. Florida Lake is a normal water body which serves as a control in this study. It is also found in the Gauteng Province of South Africa and has a GPS of S 26 10.625, E $027^{\circ} 54.220^{\prime}$ and $1673 \mathrm{~m}$ elevation. Details of the sampling sites are shown in Fig. 1.

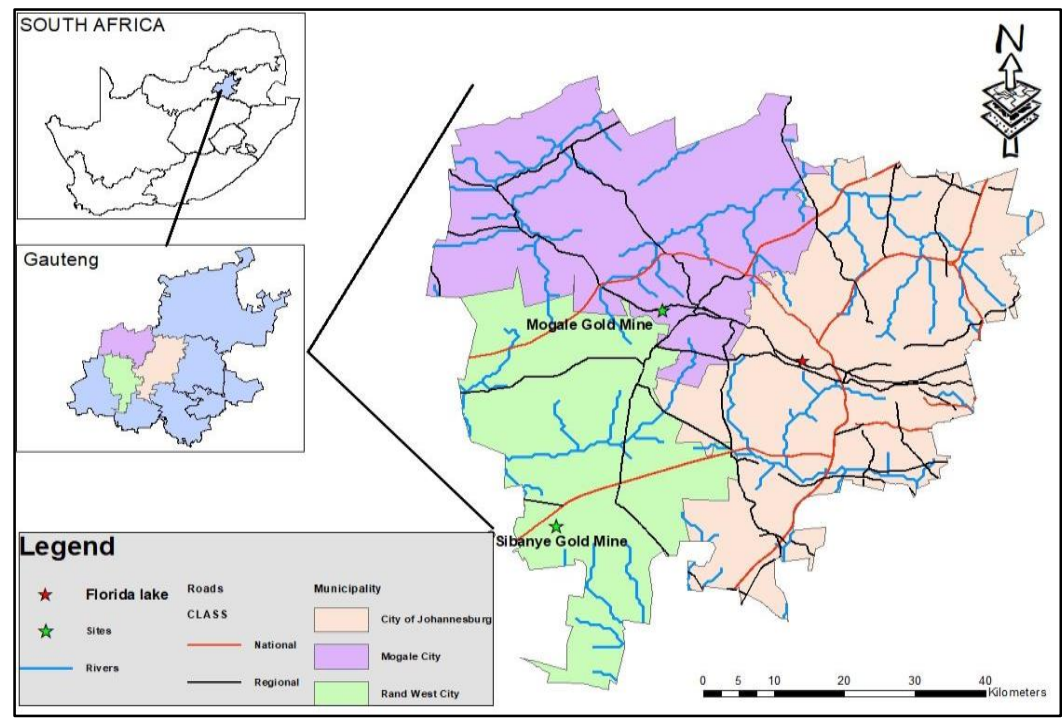

Figure 1. Map showing the sampling sites (Mogale Gold Mine, Sibanye Gold Mine and Florida Lake) 


$$
\text { - } 397 \text { - }
$$

\section{Sample Collection}

From each of three sampling sites, three sampling points were identified. Water was scooped with a bucket from each sampling point and physicochemical parameters, namely, $\mathrm{pH}$, temperature, salinity, total dissolved solutes and electrical conductivity were measured on-site using a multi-parameter ion-specific meter (Hanna instruments, version HI9828, SN 08334776). Furthermore, three rhizosphere soil samples (one sample per each uprooted reed plant that was $1 \mathrm{~m}$ apart) were collected and pooled equally to form a 1 gram sample. The soil samples were transported in ice to the laboratory where a further composite sample of 3 grams was pooled from each of the 1 gram samples which represented a sampling site. Details of the sampling and analysis done are shown in Fig. 2 and Table 1 respectively.



Figure 2. Diagrammatic representation of rhizosphere soil sample collection in a water body. Notice that the sampling was done on the edge of muddy waters. Water was scooped with a bucket from the same spots where rhizosphere soil samples were collected. This process was done on each sampling period

Table 1. Summary of the samples collected and analysis done. Lan and Wuinze 17 are acid mine sites and Florida Lake is a normal water body

\begin{tabular}{c|c|c}
\hline Sampling sites & Samples collected & Analysis done \\
\hline Wuinze 17 & Water & Physicochemical properties \\
Wuinze 17 & Rhizosphere soil & Biodiversity and secondary metabolite profile \\
Florida Lake & Water & Physicochemical properties \\
Florida Lake & Rhizosphere soil & Biodiversity and secondary metabolite profile \\
Lan 3 & Water & Physicochemical properties \\
Lan 3 & Rhizosphere soil & Biodiversity and secondary metabolite profile \\
\hline
\end{tabular}

\section{Assessment of Microbial Community Functional Diversity}

Within two hours of sampling three grams of rhizosphere soil (one composite sample for each of the three sites) were mixed with $27 \mathrm{~mL}$ of sterile $0.85 \%$ sodium chloride solution, vortexed for five minutes and the silt was allowed to settle for an additional five minutes. $180 \mu \mathrm{L}$ of the water fraction was dispensed into each of the 96 wells of the BIOLOG Ecoplate. One BIOLOG Ecoplate was used for each of the sampling sites and 
therefore a total of three plates were used per sampling regime resulting in a total of 9 plates used for the three regimes. The plates were sealed with parafilm and incubated in the dark at $25^{\circ} \mathrm{C}$. Absorbance was measured at $590 \mathrm{~nm}$ with a VarioSkan Flash (Thermoscientific) absorbance scanner at 0, 24, 48, 72, 96 and 120 hours after incubation. The purple coloration of the BIOLOG Ecoplate is an indication of the substrate utilization and functional diversity. The measured absorbance is used to calculate the Shannon index of biodiversity which indicates the measure of the microbial community present in the sampling sites.

\section{Physicochemical Data Analysis}

Measurements of physicochemical parameters were analyzed by analysis of variance (ANOVA). One way ANOVA was done using SAS version 9.4 with a significant level of $\mathrm{p}<0.05$. Post hoc testing was carried out using the Tukey test to test the differences among all possible pairs of treatments. The mean and standard deviation of all the samples were recorded for each sampling sites. Results of this analysis are presented in Table 2A-C.

Table 2A. Rhizosphere soil and water collected from the three sampling sites (Wuinze 17 at Sibanye Gold Mine, Florida Lake at Florida Roodepoort, and Lan 3 at Minitails Mogale Gold Mine) on September 2017

\begin{tabular}{|c|c|c|c|c|c|c|}
\hline Sample ID & Temp. & EC & TDS & Sa & pH & SI \\
\hline $\mathrm{WW}^{\mathrm{W} 1} 1$ & $12 \pm 1.23^{c}$ & $2286 \pm 128.3^{b}$ & $1969.50 \pm 15.9^{b}$ & $1.59 \pm 0.05^{b}$ & $6.12 \pm 1.58^{b}$ & NA \\
\hline ww2 2 & $12 \pm 1.23^{c}$ & $2286 \pm 128.3^{b}$ & $1969.50 \pm 15.9^{b}$ & $1.59 \pm 0.05^{b}$ & $6.12 \pm 1.58^{b}$ & NA \\
\hline ww33 & $12 \pm 1.23^{\mathrm{c}}$ & $2286 \pm 128.3^{b}$ & $1969.50 \pm 15.9^{b}$ & $1.59 \pm 0.05^{b}$ & $6.12 \pm 1.58^{b}$ & NA \\
\hline${ }^{\mathrm{wS}} 14$ & NA & NA & NA & NA & NA & $3.24 \pm 0.13^{b}$ \\
\hline ws25 & NA & NA & NA & NA & NA & $3.24 \pm 0.13^{b}$ \\
\hline${ }^{\mathrm{wS} 3} 6$ & NA & NA & NA & NA & NA & $3.24 \pm 0.13^{b}$ \\
\hline${ }^{\mathrm{FW}} 47$ & $16.0 \pm 1.46^{\mathrm{b}}$ & $167.9 \pm 4.56^{\mathrm{c}}$ & $135.2 \pm 19.5^{\mathrm{c}}$ & $0.10 \pm 0.02^{\mathrm{c}}$ & $8.11 \pm 2.53^{\mathrm{a}}$ & NA \\
\hline${ }^{\mathrm{FW} 5} 8$ & $16.0 \pm 1.46^{\mathrm{b}}$ & $167.9 \pm 4.56^{\mathrm{c}}$ & $135.2 \pm 19.5^{\mathrm{c}}$ & $0.10 \pm 0.02^{\mathrm{c}}$ & $8.11 \pm 2.53^{\mathrm{a}}$ & NA \\
\hline FW69 & $16.0 \pm 1.46^{\mathrm{b}}$ & $167.9 \pm 4.56^{\mathrm{c}}$ & $135.2 \pm 19.5^{\mathrm{c}}$ & $0.10 \pm 0.02^{\mathrm{c}}$ & $8.11 \pm 2.53^{\mathrm{a}}$ & NA \\
\hline${ }^{\mathrm{FS} 4} 10$ & NA & NA & NA & NA & NA & $4.55 \pm 2.60^{\mathrm{a}}$ \\
\hline FS5 11 & NA & NA & NA & NA & NA & $4.55 \pm 2.60^{\mathrm{a}}$ \\
\hline FS6 12 & NA & NA & NA & NA & NA & $4.55 \pm 2.60^{\mathrm{a}}$ \\
\hline LW713 & $22.3 \pm 2.04^{\mathrm{a}}$ & $6142 \pm 267.8^{\mathrm{a}}$ & $4407 \pm 236.9^{\mathrm{a}}$ & $3.75 \pm 0.89^{\mathrm{a}}$ & $5.03 \pm 1.56^{\mathrm{c}}$ & NA \\
\hline LW8 14 & $22.3 \pm 2.04^{\mathrm{a}}$ & $6142 \pm 267.8^{\mathrm{a}}$ & $4407 \pm 236.9^{\mathrm{a}}$ & $3.75 \pm 0.89^{\mathrm{a}}$ & $5.03 \pm 1.56^{\mathrm{c}}$ & NA \\
\hline LW9 15 & $22.3 \pm 2.04^{\mathrm{a}}$ & $6142 \pm 267.8^{\mathrm{a}}$ & $4407 \pm 236.9^{\mathrm{a}}$ & $3.75 \pm 0.89^{\mathrm{a}}$ & $5.03 \pm 1.56^{\mathrm{c}}$ & NA \\
\hline${ }^{\mathrm{LS}} 16$ & NA & NA & NA & NA & NA & $2.89 \pm 0.04^{\mathrm{c}}$ \\
\hline${ }^{\mathrm{LS}} 17$ & NA & NA & NA & NA & NA & $2.89 \pm 0.04^{\mathrm{c}}$ \\
\hline${ }_{\text {LS9 }}^{18}$ & NA & NA & NA & NA & NA & $2.89 \pm 0.04^{\mathrm{c}}$ \\
\hline
\end{tabular}

Mean \pm standard deviation. Mean with the same superscript letters are not significant at $p<0.05$. On the sample ID, the first superscript letter is for the site (W=Wuinze 17, F=Florida Lake, L=Lan 3), the second superscript letter is for sample type (W=Water, $\mathrm{S}=$ Soil), and the superscript number is for sampling points (1-9). Three rhizosphere soil samples were collected from each of the nine points (1-9) shown in Fig. 2. From each sampling point, water was also scooped and its temperature (Temp.), electrical conductivity (EC), total dissolved solids (TDS), salinity (Sa), and $\mathrm{pH}$ determined. Shannon indices (SI) of soil samples collected from two acid mine sites (W 1-3 for Wuinze 17 sampling points; and L 7-9 for Lan 3 sampling points) and the non-acid mine site (F 4-6 for Florida Lake) are represented 
Table 2B. Rhizosphere soil and water collected from the three sampling sites (Wuinze 17 at Sibanye Gold Mine, Florida Lake at Florida Roodepoort, and Lan 3 at Minitails Mogale Gold Mine) on November 2017

\begin{tabular}{|c|c|c|c|c|c|c|}
\hline Sample ID & Temp. & EC & TDS & Sa & pH & SI \\
\hline${ }^{\mathrm{wW} 1} 1$ & $10.7 \pm 1.05^{c}$ & $1724 \pm 104.6^{\mathrm{b}}$ & $1546.3 \pm 12.7^{b}$ & $1.22 \pm 0.03^{b}$ & $6.54 \pm 1.08^{b}$ & NA \\
\hline $\mathrm{ww}^{2} 2$ & $10.7 \pm 1.05^{\mathrm{c}}$ & $1724 \pm 104.6^{\mathrm{b}}$ & $1546.3 \pm 12.7^{b}$ & $1.22 \pm 0.03^{b}$ & $6.54 \pm 1.08^{b}$ & NA \\
\hline ww33 & $10.7 \pm 1.05^{\mathrm{c}}$ & $1724 \pm 104.6^{\mathrm{b}}$ & $1546.3 \pm 12.7^{b}$ & $1.22 \pm 0.03^{b}$ & $6.54 \pm 1.08^{b}$ & NA \\
\hline $\mathrm{wS1}_{4}$ & NA & NA & NA & NA & NA & $2.81 \pm 0.08^{b}$ \\
\hline ws2 5 & NA & NA & NA & NA & NA & $2.81 \pm 0.08^{b}$ \\
\hline${ }^{\mathrm{ws} 3} 6$ & NA & NA & NA & NA & NA & $2.81 \pm 0.08^{b}$ \\
\hline${ }^{\mathrm{FW}} 47$ & $14.2 \pm 1.11^{\mathrm{b}}$ & $111.9 \pm 2.74^{\mathrm{c}}$ & $102.4 \pm 14.3^{\mathrm{c}}$ & $0.05 \pm 0.01^{\mathrm{c}}$ & $7.05 \pm 1.12^{\mathrm{a}}$ & NA \\
\hline $\mathrm{FW}^{5} 8$ & $14.2 \pm 1.11^{\mathrm{b}}$ & $111.9 \pm 2.74^{\mathrm{c}}$ & $102.4 \pm 14.3^{\mathrm{c}}$ & $0.05 \pm 0.01^{\mathrm{c}}$ & $7.05 \pm 1.12^{\mathrm{a}}$ & NA \\
\hline FW69 & $14.2 \pm 1.11^{\mathrm{b}}$ & $111.9 \pm 2.74^{\mathrm{c}}$ & $102.4 \pm 14.3^{\mathrm{c}}$ & $0.05 \pm 0.01^{\mathrm{c}}$ & $7.05 \pm 1.12^{\mathrm{a}}$ & NA \\
\hline${ }^{\mathrm{FS} 4} 10$ & NA & NA & NA & NA & NA & $3.34 \pm 0.04^{\mathrm{a}}$ \\
\hline FS5 11 & NA & NA & NA & NA & NA & $3.34 \pm 0.04^{\mathrm{a}}$ \\
\hline${ }^{\mathrm{FS}} 612$ & NA & NA & NA & NA & NA & $3.34 \pm 0.04^{\mathrm{a}}$ \\
\hline${ }_{\mathrm{LW} 7} 13$ & $19.87 \pm 1.2^{\mathrm{a}}$ & $4236 \pm 148.2^{\mathrm{a}}$ & $3682 \pm 156.2^{\mathrm{a}}$ & $3.10 \pm 0.36^{\mathrm{a}}$ & $5.87 \pm 1.15^{\mathrm{c}}$ & NA \\
\hline LW8 14 & $19.87 \pm 1.2^{\mathrm{a}}$ & $4236 \pm 148.2^{\mathrm{a}}$ & $3682 \pm 156.2^{\mathrm{a}}$ & $3.10 \pm 0.36^{\mathrm{a}}$ & $5.87 \pm 1.15^{\mathrm{c}}$ & NA \\
\hline${ }_{\text {LW9 }} 15$ & $19.87 \pm 1.2^{\mathrm{a}}$ & $4236 \pm 148.2^{\mathrm{a}}$ & $3682 \pm 156.2^{\mathrm{a}}$ & $3.10 \pm 0.36^{\mathrm{a}}$ & $5.87 \pm 1.15^{\mathrm{c}}$ & NA \\
\hline${ }^{\mathrm{LS}} 16$ & NA & NA & NA & NA & NA & $2.7 \pm 0.12^{c}$ \\
\hline${ }^{\mathrm{LS}} 817$ & NA & NA & NA & NA & NA & $2.7 \pm 0.12^{\mathrm{c}}$ \\
\hline${ }_{\text {LS9 }} 18$ & NA & NA & NA & NA & NA & $2.7 \pm 0.12^{\mathrm{c}}$ \\
\hline
\end{tabular}

Mean \pm standard deviation. Mean with the same superscript letters are not significant at $p<0.05$. On the sample ID, the first superscript letter is for the site (W=Wuinze 17, F=Florida Lake, $\mathrm{L}=\mathrm{Lan} 3$ ), the second superscript letter is for sample type (W=Water, $\mathrm{S}=$ Soil), and the superscript number is for sampling points (1-9). Three rhizosphere soil samples were collected from each of the nine points (1-9) shown in Fig. 2. From each sampling point, water was also scooped and its temperature (Temp.), electrical conductivity (EC), total dissolved solids (TDS), salinity (Sa), and $\mathrm{pH}$ determined. Shannon index (SI) of samples collected from two acid mine sites (W 1-3 for Wuinze 17 sampling points; and L 7-9 for Lan 3 sampling points) and the non-acid mine site (F 4-6 for Florida Lake) are represented

\section{Biodiversity Data Analysis}

Absorbance values obtained from the VarioSkan Flash absorbance scanner were adjusted by subtracting the baseline absorbance value (0-hour absorbance). The 96-hour absorbance values differentiated between the three water bodies the most and were, therefore, the only ones considered for further analysis. The Shannon index of diversity $(H)$ was calculated following the approach of Gryta et al. (2014). One way analysis of variance (ANOVA) was done on all the biodiversity indicators using SAS version 9.4 at a significant level of $\mathrm{p}<0.05$. Shannon index was correlated with temperature, electrical conductivity, total dissolved solutes, salinity, and $\mathrm{pH}$; and 0.8 and -0.8 were set as the cut-off for Pearson correlation coefficients at a significant level of $\mathrm{p}<0.05$ (Table 3). Results of the microbial diversity are presented in Table $2 A-C$ and Fig. 3.

\section{Secondary Metabolite Shift Assessment}

Secondary metabolite profiles of rhizosphere soil from the three sites were done using a $600 \mathrm{MHz}$ Varian NMR spectroscopy. NMR spectra were processed with ACD/NMR 
and principal component analysis of intensity data was analysed using MetaboAnalyst. Principal component analysis plots are presented in Fig. 4.

Table 2C. Rhizosphere soil and water collected from the three sampling sites (Wuinze 17 at Sibanye Gold Mine, Florida Lake at Florida Roodepoort, and Lan 3 at Minitails Mogale Gold Mine) on June 2018

\begin{tabular}{|c|c|c|c|c|c|c|}
\hline Sample ID & Temp. & EC & TDS & Sa & pH & SI \\
\hline${ }^{\mathrm{WW} 1} 1$ & $7.9 \pm 0.31^{b}$ & $1791.3 \pm 10.9^{b}$ & $1557.2 \pm 1.15^{b}$ & $1.24 \pm 0.02^{b}$ & $6.50 \pm 0.31^{b}$ & NA \\
\hline$w^{w} 2$ & $7.9 \pm 0.31^{\mathrm{b}}$ & $1791.3 \pm 10.9^{b}$ & $1557.2 \pm 1.15^{\mathrm{b}}$ & $1.24 \pm 0.02^{b}$ & $6.50 \pm 0.31^{b}$ & NA \\
\hline ww33 & $7.9 \pm 0.31^{\mathrm{b}}$ & $1791.3 \pm 10.9^{b}$ & $1557.2 \pm 1.15^{\mathrm{b}}$ & $1.24 \pm 0.02^{b}$ & $6.50 \pm 0.31^{b}$ & NA \\
\hline $\mathrm{ws1}_{4}$ & NA & NA & NA & NA & NA & $3.33 \pm 0.05^{\mathrm{a}}$ \\
\hline ws2 5 & NA & NA & NA & NA & NA & $3.33 \pm 0.05^{\mathrm{a}}$ \\
\hline${ }^{\mathrm{ws} 3} 6$ & NA & NA & NA & NA & NA & $3.33 \pm 0.05^{\mathrm{a}}$ \\
\hline $\mathrm{FW}^{4} 7$ & $5.4 \pm 0.2^{\mathrm{c}}$ & $114.5 \pm 0.36^{c}$ & $119.3 \pm 0.42^{c}$ & $0.09 \pm 0.01^{\mathrm{c}}$ & $7.20 \pm 0.01^{\mathrm{a}}$ & NA \\
\hline FW5 8 & $5.4 \pm 0.2^{\mathrm{c}}$ & $114.5 \pm 0.36^{\mathrm{c}}$ & $119.3 \pm 0.42^{\mathrm{c}}$ & $0.09 \pm 0.01^{\mathrm{c}}$ & $7.20 \pm 0.01^{\mathrm{a}}$ & NA \\
\hline FW69 & $5.4 \pm 0.2^{\mathrm{c}}$ & $114.5 \pm 0.36^{\mathrm{c}}$ & $119.3 \pm 0.42^{\mathrm{c}}$ & $0.09 \pm 0.01^{\mathrm{c}}$ & $7.20 \pm 0.01^{\mathrm{a}}$ & NA \\
\hline${ }^{\mathrm{FS}} 410$ & NA & NA & NA & NA & NA & $3.34 \pm 0.01^{\mathrm{a}}$ \\
\hline FS5 11 & NA & NA & NA & NA & NA & $3.34 \pm 0.01^{\mathrm{a}}$ \\
\hline FS6 12 & NA & NA & NA & NA & NA & $3.34 \pm 0.01^{\mathrm{a}}$ \\
\hline${ }^{\mathrm{LW}} 13$ & $12.3 \pm 0.15^{\mathrm{a}}$ & $4424.3 \pm 1.15^{a}$ & $3823 \pm 1.0^{\mathrm{a}}$ & $3.20 \pm 0.10^{\mathrm{a}}$ & $5.53 \pm 0.11^{\mathrm{c}}$ & NA \\
\hline${ }^{\mathrm{LW}} 814$ & $12.3 \pm 0.15^{\mathrm{a}}$ & $4424.3 \pm 1.15^{a}$ & $3823 \pm 1.0^{\mathrm{a}}$ & $3.20 \pm 0.10^{\mathrm{a}}$ & $5.53 \pm 0.11^{\mathrm{c}}$ & NA \\
\hline${ }^{\text {LW9 }} 15$ & $12.3 \pm 0.15^{a}$ & $4424.3 \pm 1.15^{a}$ & $3823 \pm 1.0^{\mathrm{a}}$ & $3.20 \pm 0.10^{\mathrm{a}}$ & $5.53 \pm 0.11^{\mathrm{c}}$ & NA \\
\hline${ }_{\text {LS7 }} 16$ & NA & NA & NA & NA & NA & $2.80 \pm 0.71^{b}$ \\
\hline LS8 17 & NA & NA & NA & NA & NA & $2.80 \pm 0.71^{b}$ \\
\hline${ }_{\text {LS9 }} 18$ & NA & NA & NA & NA & NA & $2.80 \pm 0.71^{\mathrm{b}}$ \\
\hline
\end{tabular}

Mean \pm standard deviation. Mean with the same superscript letters are not significant at $\mathrm{p}<0.05$. On the sample ID, the first superscript letter is for the site (W=Wuinze 17, F=Florida Lake, $\mathrm{L}=\mathrm{Lan} 3$ ), the second superscript letter is for sample type (W=Water, $\mathrm{S}=$ Soil), and the superscript number is for sampling points (1-9). Three rhizosphere soil samples were collected from each of the nine points (1-9) shown in Fig. 2. From each sampling point, water was also scooped and its temperature (Temp.), electrical conductivity (EC), total dissolved solids (TDS), salinity (Sa), and pH determined. Shannon index (SI) of samples collected from two acid mine sites (W 1-3 for Wuinze 17 sampling points; and L 7-9 for Lan 3 sampling points) and the non-acid mine site (F 4-6 for Florida Lake) are represented

Table 3. Correlation coefficients of the Shannon index of biodiversity and the physicochemical parameters for rhizosphere soil and water samples collected from the sampling points

\begin{tabular}{c|ccc}
\hline \multirow{2}{*}{ Parameters } & \multicolumn{3}{|c}{ Shannon index of biodiversity } \\
\cline { 2 - 4 } & September 2017 & November 2017 & June 2018 \\
\hline pH & 0.48 & 0.24 & 0.95 \\
Temperature & -0.20 & -0.88 & -0.97 \\
Salinity & -0.47 & -0.29 & -0.97 \\
TDS & -0.46 & -0.27 & -0.97 \\
EC & -1.00 & -0.88 & -0.96 \\
\hline
\end{tabular}

Values greater or equal to 0.80 or- 0.80 are taken as the threshold cut off in this study $(n=3)$. Correlation is significant at the level $\mathrm{p}<0.05$. TDS and EC stand for total dissolved solids and electrical conductivity 


$$
-401-
$$

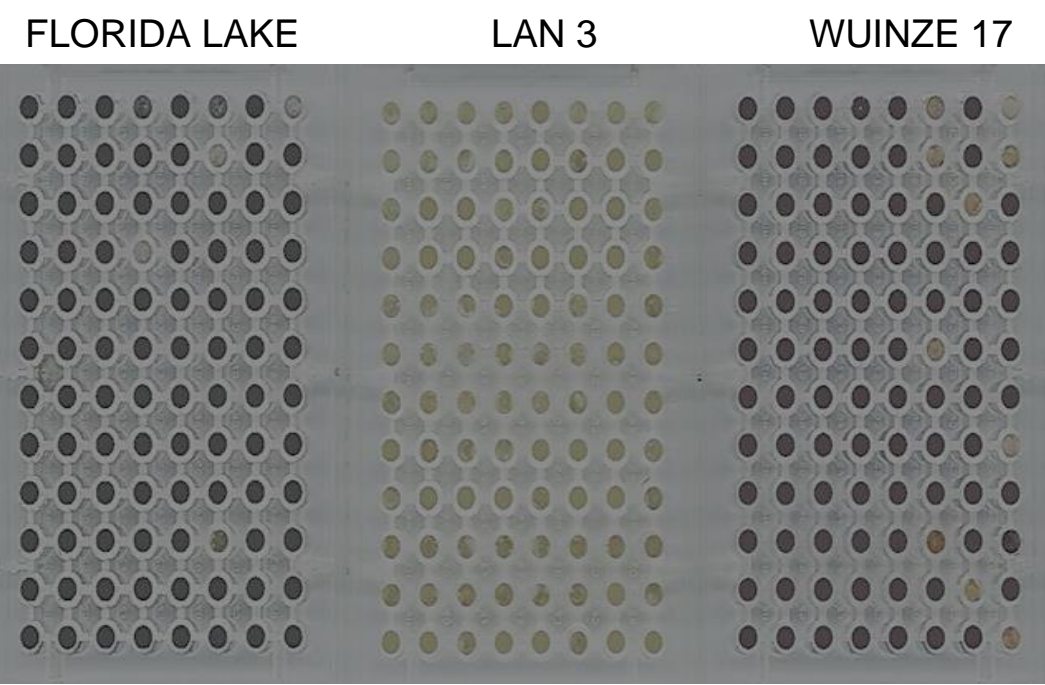

Figure 3. Ninety-six well BIOLOG Ecoplates showing catabolic activities of the microbial community of the rhizosphere of Phragmites australis after 96 hours of incubation. The ecoplates are precoated with 31 carbon substrates and the purple colour of the well indicates utilization of the substrate by the microbes in the water. Notice that no substrate turned purple in the middle 96 well ecoplate showing complete loss of microbial activities as a result of acid mine drainage. All the sets of BIOLOG Ecoplates looked similar and therefore only one set (sampled in September 2017) was shown

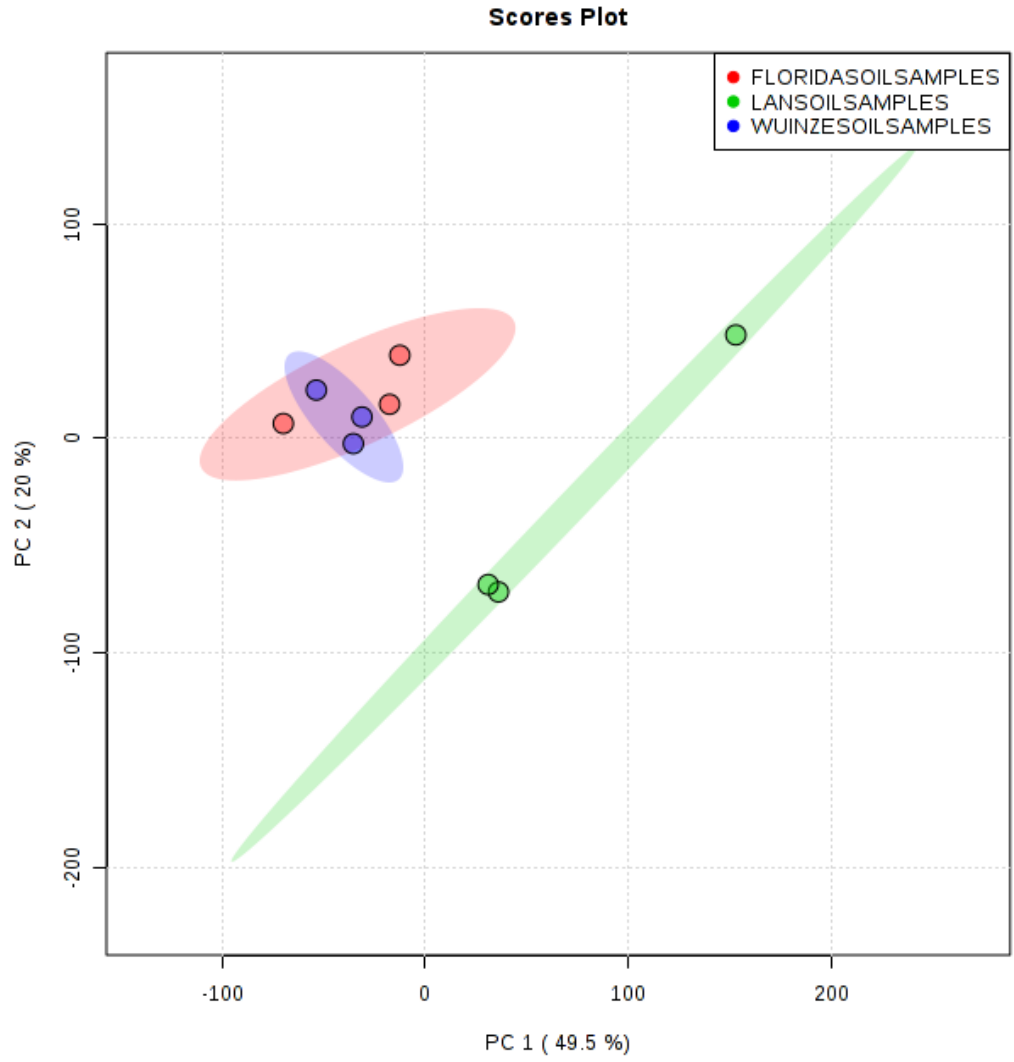

Figure 4. Principal component analysis showing the secondary metabolite shifts of soil samples of Phragmites australis. Florida Lake and Wuinze 17 clustered together indicating closeness in their metabolites. The metabolites of Lan 3 were differentiated from the other two sites 


\section{Results}

Measurements of physicochemical parameters of the water bodies confirmed that the sites selected as acid mine sites indeed showed characteristics of acid mine pollution and the normal site had characteristics of a regular water body. This was shown by the low $\mathrm{pH}$, and high electrical conductivity (EC) and total dissolved solids (TDS) values in the acid mine sites and relatively normal in the water samples from Florida Lake and also the significant difference at $\mathrm{p}<0.05$ across the three sampling sites for the physicochemical parameters. The applications of BIOLOG EcoPlates in the evaluation of microbial diversity by many researchers have proven to be effective in providing a good indication of microbial diversity (Wang et al., 2008; Nautiyal et al., 2010; Ling et al., 2012; Zhang et al., 2013, 2014; Deng et al., 2014; Xu et al., 2015; Liu et al., 2015; Raghawendra et al., 2019). In this study, BIOLOG EcoPlates were used to measure the microbial diversity of rhizosphere soil of Phragmites australis. Microbial diversity in the two acid mine sites was reduced compared to the normal water body. However, the Wuinze 17 site retained most of its microbial diversity despite having a relatively high electrical conduction and low $\mathrm{pH}$ characteristic of acid mine water. Although these parameters had values higher than those of Florida they were still far less than those of the very harsh Lan 3 site. Proton NMR spectroscopy has also proved effective in secondary metabolite profiling of different samples (Blow, 2008; De Meyer et al., 2008; Nicholson and Lindon, 2008; Alves et al., 2009; Pontoizeau et al., 2010; Ravanbakhsh et al., 2015; Alonso et al., 2015). The secondary metabolites profiles as observed in this study showed diversity among the sampling sites. However, one of the acid mine sites (Wuinze 17) showed close clustering of the metabolites with the normal water body (Florida Lake). This could be attributed to the ability of the rhizosphere microbes associated with Phragmites australis to increase the $\mathrm{pH}$ of Wuinze 17 that was 1.03 above the $\mathrm{pH}$ of Lan 3 site (an acid mine site) to meet the acceptable limits of DWAF (1996) guidelines as well as the not so high EC in Wuinze 17. This could lead to the production of metabolites similar to the ones produced by the microbes in Florida Lake.

\section{Physicochemical Characteristics}

The results of the physicochemical parameters showed that there were significant differences between each of the parameters across the two acid mine sites (Wuinze 17 and Lan 3) and the non-acid mine site (Florida Lake) (Table 2A-C). The acid mine drainage samples from the two acid mine sites (Wuinze 17 and Lan 3) showed higher electrical conductivity, salinity, total dissolved solids and low $\mathrm{pH}$ when compared to the non-acid mine drainage (Florida Lake) (Table $2 A-C$ ). The findings of many researchers have shown acid mine drainage to be characterized by $\mathrm{pH}$ values that are less than five (Dagmar Kock, 2008; Denef et al., 2010; USGS, 2012; Masindi et al., 2015; Chen et al., 2016; Teng et al., 2017). The guidelines stipulated for acid mine treated water according to DWAF (1996) are $6-9$ for $\mathrm{pH}, 0-1200 \mathrm{mg} / \mathrm{L}$ for total dissolved solutes, and $0-450 \mu \mathrm{S} / \mathrm{cm}$ for electrical conductivity. The $\mathrm{pH}$ values of Wuinze 17 (acid mine site) and Florida Lake (normal water body) were observed to be within the recommended guideline. This could be an indication of more remediation activities of Phragmites australis and the associated rhizosphere microbes in Wuinze 17 than in Lan 3. This could be attributed to the difference in the $\mathrm{pH}$ between the two acid mine drainage sites that ranges from 0.67 to 1.09 . Furthermore, the electrical conductivity and total dissolved 
solids of Florida Lake was within the required guideline confirming the lake as a regular water body.

\section{Microbial Community Functional Diversity}

In this study, the Shannon index of biodiversity was done to assess the microbial diversity of the two acid mine water and the non-acid mine water. High Shannon index indicates more diversity of microbial communities in the sampling sites. The non-acid mine water showed more diversity than the acid mine water.

\section{Shannon Index of Biodiversity}

The Shannon indices differ significantly across the three sampling sites in this study (Table 2A-C and Fig. 3). Florida Lake (non-acid mine drainage site) was observed to be more diversified in the microbial community than the two acid mine sites (Wuinze 17 and Lan 3). The Shannon diversity index of Florida Lake was higher than the two acid mine sites and this was also shown by the higher number of BIOLOG Ecoplate wells which had turned purple indicating the presence of microbes that had the potential to utilize the substrate pre-coated in the well. Wuinze 17 showed higher Shannon index values than Lan 3 presenting Lan 3 as the less diversified site.

\section{Correlation analysis of the Shannon index of Biodiversity and Physicochemical Parameters}

The acid mine drainage influenced the microbial diversity of the common reed's rhizosphere. This finding is based on the correlation between the physicochemical parameters and the Shannon index (Table 3). Pearson correlation coefficients of 0.8 and -0.8 were set as the cut-off in this study at a significant level of $p<0.05$. Correlated with salinity and total dissolved solute, the SI had a negative correlation coefficient with the highest negative correlation recorded in the third sampling. The negative correlation means that as salinity and total dissolved solids increase, the rhizosphere microbial diversity decreases. Similarly, electric conductivity showed a strong negative correlation with the Shannon index of biodiversity in all the three sampling periods. However, $\mathrm{pH}$ showed a positive correlation with the Shannon index with the strongest correlation recorded in the third sampling period. This positive correlation implied that the increase in $\mathrm{pH}$ results in the corresponding increase in microbial diversity. This correlation study provided an insight into the response of the microbial diversity with changes in environmental conditions.

\section{Secondary Metabolites Assessment}

The acid mine drainage influenced the secondary metabolite compositions of the rhizosphere soil and roots of Phragmites australis. This is evident in the metabolite profiles observed in the principal component analysis (PCA) of secondary metabolites in the soil samples (Fig. 4). Surprisingly, the non-acid mine Florida Lake and the acid mine Wuinze17 soil samples showed similar metabolite shift that differs from Lan 3 soil samples. It was expected that the acid mine sites would cluster together instead of the grouping of Florida Lake and Wuinze 17 which resulted from the PCA of NMR data. This could be attributed to the normality of Florida Lake and the fact that Wuinze 17 is not static water and therefore receives fresh supplies of water which may sometimes be fresh. Furthermore, the compliance of the $\mathrm{pH}$ values of the two sites to the DWAF (1996) 
guidelines could be another contributing factor to the clustering of the sites. This is reaffirm by the closeness of Shannon index of both sites indicating the presence of similar microbes capable of producing similar metabolites.

\section{Discussion}

Although there are dynamics in studies investigating aspects of pollution due to mining, conclusions drawn from these studies confirm the loss of biodiversity as a result of pollution. As such the production of secondary metabolites by the affected organisms is likely to change to reflect the new natural imbalances. This phenomenon was further re-established in this work. However, the focus of the authors of this manuscript was on microbes associated with the rhizosphere of Phragmites australis because of their role in bioremediation and the uniqueness of their habitat. Efforts in ecosystem restoration in acid mine environments needs to focus on preserving rhizosphere associated microbes to maintain their mutual relationship with their associated bioremediating plant. Results of this study clearly showed that the diversity of the $P$. australis rhizosphere associated microbes of the two acids mine drainage sites (Wuinze 17 and Lan 3) were reduced when compared to the non-acid mine drainage site (Florida Lake) in all the sampling periods. The correlation between the physicochemical parameters and the Shannon index of biodiversity showed that the acid mine drainage influenced microbial diversity (Table 3). The secondary metabolite analysis showed metabolite shifts among the soil samples in the three sampling sites indicating diversity and difference in their secondary metabolite composition.

The reasons for the loss of diversity in the acid mine sites in this study could have been caused by the $\mathrm{pH}$ gradient. A neutral $\mathrm{pH}$ of 7 could pose no environmental problems to the existing organisms. Brady and Weil (1996) suggested that extreme $\mathrm{pH}$ affects the survival of microorganisms directly or indirectly via the control of auxillary environmental parameters relating to $\mathrm{pH}$ like nutrient availability and cationic metal solubility. This suggestion was supported by the work done by Amaral-Zettler et al. (2011), Li et al. (2014), Sun et al. (2014) and Sun et al. (2015) who observed that pH affects the microbial structure and composition of environments. Kuang et al. (2013) stated that the acidic nature of acid mine drainage water tends to pose a major risk factor to existing diversity of microbial community and structure when discharged directly into water bodies. Furthermore, many researchers have reported that the low $\mathrm{pH}$ in acid mine drainage water accelerates the solubility of many metals, and in addition with low availability of organic carbon, it creates highly challenging and extreme environmental growth conditions for the microbial community (Dopson et al., 2003; Slonczewski et al., 2009). The work of these researchers was consistent with the results obtained in this study because the acid mine sites with low $\mathrm{pH}$ showed less microbial diversity than the non-acid mine site based on the Shannon index.

Sun et al. (2015) observed a strong correlation between temperature and microbial community. The authors further observed a strong and significant link between temperature and microbial community variance. Volant et al. (2014), and Edwards et al. (1999) reported temperature as a crucial factor that shapes the community composition of microbes in acid mine drainage. Similarly, in this present study, the temperature was observed to correlate strongly with the Shannon index of biodiversity. This finding indicated the influence of the environmental temperature on microbial community composition. However, it should be stated that the three sampling sites in this study are 
within a $17.7 \mathrm{~km}$ radius and therefore fall under the same climatic zone and therefore the difference in the water temperature was not large but had however a significant influence on the Shannon index an indication of the elasticity of the Shannon index. Further studies on water temperature and the Shannon index are recommended to deepen understanding of the dependence of microbial activity and water temperature.

Salinity can influence and possibly change soil environment leading to changes in the soil microbial composition, structure, and biomass. This implied that salinity brought about by the presence of dissolved solids in the acid mine plays a major role in determining the diversity and composition of microbes and the metabolites produced by the microbes in order to adapt to the changing environment. The correlation analysis of the Shannon index of biodiversity with the physicochemical parameters also showed that indeed salinity must have reduced diversity in this study. A plethora of similar studies agree with the results of this study (Batra and Manna, 1997; Pathak and Rao, 1998; Rousk et al., 2011; Setia et al., 2011; Andronov et al., 2012; Yan et al., 2015; Chen et al., 2017). The reduction of microbial biomass in the high saline environment is due to osmotic stress that leads to lysing and drying of cells (Laura, 1974; Sarig and Steinberger, 1994; Sarig et al., 1996; Batra and Manna, 1997; Pathak and Rao, 1998; Rietz and Haynes, 2003; Yuan et al., 2007a).

Yaish et al. (2016) discovered that soil salinity causes a reduction in the bicarbonate and calcium carbonate of the soil. A discovery that was consistent with the work done by Setia et al. (2013) where the effect of salinity in the reduction of the global carbon stocks was observed due to the reduction in the microbial activity. This implies that an increase in the salinity of the environment results in a corresponding decrease in the microbial structure and possibly the diversity. The extreme environmental condition of the acid mine drainage might be the cause of the change in the microbial activity and the diversity of the heterogeneous microbial community in this study. This was evidenced in the work done by Keshri et al. (2015) who discovered that the Vanadium mine water samples were less acidic and saline with higher bacterial diversity. This result concurs with the results obtained in this study where the Florida Lake, a non-acid mine drainage sites and Wuinze 17, an acid mine drainage site, which were less acidic were observed to have higher microbial diversity than Lan 3, an acid mine drainage site that was more acidic.

Previous studies showed a correlation between the physicochemical parameters and the microbial community composition (Dopson et al., 2003; Slonczewski et al., 2009). This present study supported the work done by Dopson et al. (2003) and Slonczewski et al. (2009) because correlation coefficients of the biodiversity indicator, showed both positive and negative correlation with different physicochemical parameters. For example, electrical conductivity showed a strong negative correction throughout the sampling periods in this study. Some studies indicated that increase in soil electrical conductivity leads to decrease in soil respiration and consequently affect the soil microbial community (Adviento-Borbe et al., 2006; Yuan et al., 2007b; Wong et al., 2009). These results were in agreement with the results obtained in this study where the two acid mine sites with high electrical conductivity experienced low microbial diversity in terms of the Shannon index. This reduction in Shannon index could be attributed to the reduction in the cell respiration or the osmotic stress faced by the soil microbes.

There are variations in the sensitivity of enzymatic activities to varying salinity in the soil (Frankenberger and Bingham, 1982; Garcia and Hernandez, 1996; Pan et al., 2013). This could be attributed to variation in the metabolite profiles caused by the varying salinity state in the environment. Work done by many researchers has shown that 
variation in salt tolerance among microorganisms' influences the microbial community structure and metabolite profiles in saline soils more than the non-saline soils (Quesada et al., 1982; Del-Moral et al., 1987; Zahran et al., 1992; Killham, 1994; Pankhurst et al., 2001; Oren, 2001; Gros et al., 2003; Sagot et al., 2010). Furthermore, some studies have shown the relationships between enzyme activities and the metabolites produced by both plants and microbes in response to harsh environment factors (Sagot et al., 2010; Sulpice et al., 2010; Méndez-García et al., 2015; Jian et al., 2016). Similarly, in this study, the diverse metabolites produced by the microbes could be a surviving factor for those organisms and possibly be responsible for the metabolite shifts observed between the acid mine sites and non-acid mine sites in this study.

Tian et al. (2014) pointed out that for effective remediation in constructed wetlands using macrophytes like $P$. australis, microbial communities present in the rhizosphere of plant species selected for the bioremediation play major roles in promoting the growth of plants and biodegrading the contaminants. The understanding of the influence of the acid mine water on the rhizospheres' microbes in this present study unveiled the need to preserve these microbes in order to enhance the remediation processes of the macrophytes.

\section{Conclusion}

This study evaluated the influence of the acid mine drainage on the microbial diversity and metabolite shift of the common reed's rhizosphere. The evaluation was successful and provided a clear distinction of the metabolite profiles and microbial diversities of the acid mine drainage (AMD) sites and the non-acid mine drainage site. The AMD sites showed a low microbial diversity which is evident in the biodiversity indicator. However, Wuinze 17 and the non-acid mine site showed similar metabolite profile. This could be attributed to remediating ability of the microbes associated with the rhizosphere of Phragmites australis leading to the compliance of $\mathrm{pH}$ values of Wuinze 17 to DWAF (1996) guidelines and the closeness of the Shannon index of biodiversity values of both sites (Wuinze 17 and Florida Lake). The closeness in their Shannon index could imply the presence of similar microbes capable of producing similar metabolites. The present study suggests further study on the identification of the microbial communities in the three sampling sites and the remediation ability of the identified microorganisms across environmental pollutants.

Acknowledgements. The authors wish to thank the Agricultural Research Council - University of South Africa Climate Change Collaboration Centre for their financial support.

Author Contributions. Kalu Chimdi Mang performed the sample collection, data analyses and writing of the manuscript. Khayalethu Ntushelo assisted in the sample collection, data analysis and contributed immensely to the writing and editing of the manuscript.

Conflicts of Interests. The authors declared no conflict of interests. 


\section{REFERENCES}

[1] Adviento-Borbe, M. A. A., Doran, J. W., Drijber, R. A., Dobermann, A. (2006): Soil electrical conductivity and water content affect nitrous oxide and carbondioxide emissions in intensively managed soils. - Journal of Environmental Quality 35: 1999-2010.

[2] Alonso, A., Marsal, S., Julià, A. (2015): Analytical methods in untargeted metabolomics: State of the Art in 2015. - Frontiers in Bioengineering and Biotechnology 3: 23.

[3] Alves, A., Rantalainen, M., Holmes, E., Nicholson, J. K., Ebbels, T. M. D. (2009): Analytic properties of statistical total correlation spectroscopy based information recovery in ${ }^{1} \mathrm{H}$ NMR metabolic data sets. - Analytical Chemistry 81: 2075-2084.

[4] Amaral-Zettler, L. A., Zettler, E. R., Theroux, S. M., Palacios, C., Aguilera, A., Amils, R. (2011): Microbial community structure across the tree of life in the extreme Rio Tinto. ISME Journal 5: 42-50.

[5] Andronov, E. E., Petrova, S. N., Pinaev, A. G., Pershina, E. V., Rakhimgalieva, S. Z., Akhmedenov, K. M., Sergaliev, N. K. (2012): Analysis of the structure of microbial community in soils with different degrees of salinization using T-RFLP and real-time PCR techniques. - Eurasian Soilless Science 45: 147-156.

[6] Barac, T., Taghavi, S., Borremans, B., Provoost, A., Oeyen, L., Colpaert, J. V., Vangronsveld, J., van der Lelie, D. (2004): Engineered endophytic bacteria improve phytoremediation of water-soluble, volatile, organic pollutants. - Nature Biotechnology 22: 583-588.

[7] Batra, L., Manna, M. C. (1997): Dehydrogenase activity and microbial biomass carbon in salt affected soils of semi-arid and arid regions. - Arid Land Research Management 11: 295-303.

[8] Blow, N. (2008): Metabolomics: Biochemistry's new look. - Nature 455: 697-700.

[9] Blowes, D. W., Ptacek, C. J., Jambor, J. L., Weisener, C. G. (2003): The geochemistry of acid mine drainage. - In: Holland, H. D., Turekian, K. K. (eds.) Treatise on geochemistry. Oxford, Elsevier, pp. 150-204.

[10] Brady, N. C., Weil, R. R. (1996): The nature and properties of soils. - Prentice-Hall Inc., New Jersey.

[11] Bulgarelli, D., Rott, M., Schlaeppi, K., Ver Loren van Themaat, E., Ahmadinejad, N., Assenza, F., Rauf, P., Huettel, B., Reinhardt, R., Schmelzer, E., Peplies, J., Gloeckner, F. O., Amann, R., Eickhorst, T., Schulze-Lefert, P. (2012): Revealing structure and assembly cues for Arabidopsis root-inhabiting bacterial microbiota. - Nature 488: 91-95.

[12] Chen, L. X., Huang, L. N., Méndezgarcía, C., Kuang, J. L., Hua, Z. S., Liu, J., Shu, W. S. (2016): Microbial communities, processes and functions in acid mine drainage ecosystems. - Current Opinion in Biotechnology 38: 150-158.

[13] Chen, L., Li, C., Feng, Q., Wei, Y., Zheng, H., Zhao, Y., Feng, Y., Li, H. (2017): Shifts in soil microbial metabolic activities and community structures along a salinity gradient of irrigation water in a typical arid region of China. - Science of the Total Environment 598: 64-70.

[14] Dagmar Kock, A. S. (2008): Quantitative microbial community analysis of three different sulfidic mine tailing dumps generating acid mine drainage. - Applied Environmental Microbiology 74: 5211-5219.

[15] De Meyer, T., Sinnaeve, D., Van Gasse, B., Tsiporkova, E., Rietzschel, E. R., De Buyzere, M. L., Gillebert, T. C., Bekaert, S., Martins, J. C., Van Criekinge, W. (2008): NMR-based characterization of metabolic alterations in hypertension using an adaptive, intelligent binning algorithm. - Analytical Chemistry 80: 3783-3790.

[16] Del-Moral, A., Quesada, E., Ramos-Cormenzana, A. (1987): Distribution and types of bacterial isolated from an inland saltern Annales de l'Institut Pasteur. - Microbiology 138: 59-66. 
[17] Denef, V. J., Mueller, R. S., Banfield, J. F. (2010): AMD biofilms: Using model communities to study microbial evolution and ecological complexity in nature. - ISME Journal 4: 599-610.

[18] Deng, J., Brettar, I., Luo, C. W., Auchtung, J., Konstantinidis, K. T., RodriH., James, M.T. (2014): Stability, genotypic and phenotypic diversity of Shewanella baltica in the redox transition zone of the Baltic Sea. - Environmental microbiology 16: 1854-1866.

[19] Department of Water Affairs and Forestry (DWAF) (1996): Agricultural Use: Irrigation 4. - South African Water Quality Guidelines, Pretoria.

[20] Dopson, M., Baker-Austin, C., Koppineedi, P. R., Bond, P. L. (2003): Growth in sulfidic mineral environments: metal resistance mechanisms in acidophilic micro-organisms. Microbiology 149: 1959-1970.

[21] Edwards, K. J., Gihring, T. M., Banfield, J. F. (1999): Seasonal variations in microbial populations and environmental conditions in an extreme acid mine drainage environment. - Applied Environment Microbiology 65: 3627-3632.

[22] Evangelou, V. P. (1995): Pyrite Oxidation and its Control. - New York7 CRC Press, 275p.

[23] Frankenberger, W. T., Bingham, F. T. (1982): Influence of salinity on soilless enzyme activities. - Soilless Science Society of American Journal 46: 1173-1177.

[24] Garcia, C., Hernandez, T. (1996): Influence of salinity on the biological and biochemical activity of a calciorthird soil. - Plant Soilless 178: 255-263.

[25] Gros, R., Poly, F., Monrozier, L. J., Faivre, P. (2003): Plant and soil microbial community responses to solid waste leachates diffusion on grassland. - Plant Soilless 255: 445-455.

[26] Gryta, A., Frac, M., Oszust, K. (2014): The Application of the Biolog EcoPlate Approach in Ecotoxicological Evaluation of Dairy Sewage Sludge. - Applied Biochemistry and Biotechnology 174: 1434-1443.

[27] Jian, S. Y., Li, J. W., Chen, J., Wang, G. S., Mayes, M. A., Dzantor, K. E., Hui, D. F., Luo, Y. Q. (2016): Soil extracellular enzyme activities, soil carbon and nitrogen storage under nitrogen fertilization: A meta-analysis. - Soil Biology and Biochemistry 101: 32-43.

[28] Kawasaki, A., Donn, S., Ryan, P. R., Mathesius, U., Devilla, R., Jones, A., Watt, M. (2016): Microbiome and exudates of the root and rhizosphere of brachypodium distachyon, a model for wheat. - PLoS ONE 11: 1-10.

[29] Keshri, J., Mankazana, B. B. J., Momba, M. N. B. (2015): Profile of bacterial communities in South African mine-water samples using Illumina next-generation sequencing platform. - Applied Microbiology and Biotechnology 99: 3233-3242.

[30] Killham, K. (1994): Soil ecology. - Cambridge University Press, UK, pp. 152-154.

[31] Kuang, J. L., Huang, L. N., Chen, L. X., Hua, Z. S., Li, S. J., Hu, M., Li, J. T., Shu, W. S. (2013): Contemporary environmental variation determines microbial diversity patterns in acid mine drainage. - ISME Journal 7: 1038-1050.

[32] Laura, R. D. (1974): Effects of neutral salts on carbon and nitrogen mineralization of organic-matter in soil. - Plant Soilless 41: 113-127.

[33] Li, J., Sun, W., Wang, S., Sun, Z., Lin, S., Peng, X. (2014): Bacteria diversity, distribution and insight into their role in $\mathrm{S}$ and $\mathrm{Fe}$ biogeochemical cycling during black shale weathering. - Environmental Microbiology 16: 3533-3547.

[34] Ling, Q., Bao, J., Li, R., Tao, Y., Bao, Q. (2012): Analysis of carbon metabolism diversity characters of air microbes in Huangshan Scenic Spot Using Biolog-Eco Method. - Journal of Basic Science and Engineering 1: 008.

[35] Liu, B., Li, Y., Zhang, X., Wang, J., Gao, M. (2015): Effects of chlortetracycline on soil microbial communities: Comparisons of enzyme activities to the functional diversity via Biolog EcoPlates. - European Journal of Soil Biology, http: //dx.doi.org/10.1016/ j.ejsobi.2015.01.002.

[36] Masindi, V., Mugera, W. G., Hlanganani, T., Marinda, D-B. (2015): Passive remediation of acid mine drainage using cryptocrystalline magnesite: A batch experimental and geochemical modelling approach. - Water SA 41: 1-10. 
[37] Méndez-García, C., Peláez, A. I., Mesa, V., Sánchez, J., Golyshina, O. V., Ferrer, M. (2015): Microbial diversity and metabolic networks in acid mine drainage habitats. Frontier in Microbiology 6: 1-17.

[38] Muratova, A. Y., Dmitrieva, T. V., Panchenko, L. V., Turkovskaya, O. V. (2008): Phytoremediation of oil-sludge-contaminated soil. - International Journal of Phytoremediation 10: 486-502.

[39] Nautiyal, C. S., Chauhan, P. S., Bhatia, C. R. (2010): Changes in soil physicochemical properties and microbial functional diversity due to 14 years of conversion of grassland to organic agriculture in semi-arid agro ecosystem. - Soil Tillage Research 109: 55-60.

[40] Nicholson, J. K., Lindon, J. C. (2008): Systems biology: Metabonomics. - Nature 455: 1054-1056.

[41] Oren, A. (2001): The bioenergetics basis for the decrease in metabolic diversity at increasing salt concentrations: implications for the functioning of salt lake ecosystems. Hydrobiology 466: 61-72.

[42] Pan, C. C., Liu, C. A., Zhao, H. L., Wang, Y. (2013): Changes of soil physicochemical properties and enzyme activities in relation to grassland salinization. - European Journal of Soilless Biology 55: 13-19.

[43] Pankhurst, C. E., Yu, S., Hawke, B. G., Harch, B. D. (2001): Capacity of fatty acid profiles and substrate utilization patterns to describe differences in soil microbial communities associated with increased salinity or alkalinity at three locations in South Australia. Biology and Fertility of Soils 33: 204-217.

[44] Pathak, H., Rao, D. L. N. (1998): Carbon and nitrogen mineralization from added organic matter in saline and alkali soils. - Soilless Biology and Biochemistry 30: 695-702.

[45] Pétriacq, P., Williams, A., Cotton, A., McFarlane, A. E., Rolfe, S. A., Ton, J. (2017): Metabolite profiling of non-sterile rhizosphere soil. - Plant Journal 92(1): 147-162.

[46] Pontoizeau, C., Herrmann, T., Toulhoat, P., Elena-Herrmann, B., Emsley, L. (2010): Targeted projection NMR spectroscopy for unambiguous metabolic profiling of complex mixtures. - Magnetic Resonance in Chemistry 48: 727-733.

[47] Quesada, E., Ventosa, A., Ramoscormenzana, A., Rodriguezvalera, F. (1982): Types and properties of some bacteria isolated from hypersaline soils. - Journal of Applied Bacteriology 53: 155-161.

[48] Raghawendra, K., Avinash, M., Bhavanath, J. (2019): Bacterial community structure and functional diversity in subsurface seawater from the western coastal ecosystem of the Arabian Sea, India. - Gene 701: 55-64.

[49] Ravanbakhsh, S., Liu, P., Bjordahl, T. C., Mandal, R., Grant, J. R., Wilson, M., Eisner, R., Sinelnikov, I., Hu, X., Luchinat, C., Greiner, R., Wishart, D. S. (2015): Accurate, fullyautomated NMR spectral profiling for metabolomics. - PLoS ONE 10: e0124219.

[50] Rietz, D. N., Haynes, R. J. (2003): Effects of irrigation-induced salinity and sodicity on soil microbial activity. - Soilless Biology and Biochemistry 35: 845-854.

[51] Robertson-Albertyn, S., Terrazas, R. A., Balbirnie, K., Blank, M., Janiak, A., Szarejko, I., Chmielewska, B., Karcz, J., Morris, J., Hedley, P. E., George, T. S., Bulgarelli, D. (2017): Root Hair Mutations Displace the Barley Rhizosphere Microbiota. - Frontier in Plant Science 8: 1-15.

[52] Rousk, J., Elyaagubi, F. K., Jones, D. L., Godbold, D. L. (2011): Bacterial salt tolerance is unrelated to soil salinity across an arid agroecosystem salinity gradient. - Soilless Biology and Biochemiistry 43: 1881-1887.

[53] Sagot, B., Gaysinski, M., Mehiri, M., Guigonis, J. M., LeRudulier, D., Alloing, G. (2010): Osmotically induced synthesis of the dipeptide $\mathrm{N}$-acetyl glutaminyl glutamine amide is mediated by a new pathway conserved among bacteria. - Proceedings of the National Academy of Sciences 107: 12652-12657.

[54] Sarig, S., Steinberger, Y. (1994): Microbial biomass response to seasonal fluctuation in soil-salinity under the canopy of desert halophytes. - Soilless Biology and Biochemistry 26: $1405-1408$. 


$$
-410 \text { - }
$$

[55] Sarig, S., Fliessbach, A., Steinberger, Y. (1996): Microbial biomass reflects a nitrogen and phosphorous economy of halophytes grown in salty desert soil. - Biology and Fertility of Soils 21: 128-130.

[56] Scholes, L. N. L., Shutes, R. B. E., Revitt, D. M., Purchase, D., Forshaw, M. (1999): The removal of urban pollutants by constructed wetlands during wet weather. - Water Science and Technology 40: 333-340.

[57] Setia, R., Marschner, P., Baldock, J., Chittleborough, D., Verma, V. (2011): Relationships between carbondioxide emission and soil properties in salt-affected landscapes. - Soilless Biology and Biochemistry 43: 667-674.

[58] Setia, R., Gottschalk, P., Smith, P., Marschner, P., Baldock, J., Setia, D., Smith, J. (2013): Soil salinity decreases global soil organic carbon stocks. - Science of the Total Environment 465: 267-272.

[59] Slonczewski, J. L., Fujisawa, M., Dopson, M., Krulwich, T. A., Robert, K. P. (2009): Cytoplasmic $\mathrm{pH}$ measurement and homeostasis in bacteria and archaea. - Advance in Microbiology and Physiology 55: 1-79.

[60] Sulpice, R., Trenkamp, S., Steinfath, M., Usadel, B., Gibon, Y., Witucka-Wall, H., Pyl, E. T., Tschoep, H., Steinhauser, M. C., Guenther, M., Hoehne, M., Rohwer, J. M., Altmann, T., Fernie, A. R., Stitt, M. (2010): Network analysis of enzyme activities and metabolite levels and their relationship to biomass in a large panel of Arabidopsis accessions. - The Plant Cell 22: 2872-2893.

[61] Sun, M., Xiao, T. F., Ning, Z. P., Xiao, E., Sun, W. M. (2014): Microbial community analysis in rice paddy soils irrigated by acid mine drainage contaminated water. - Applied Microbiology and Biotechnology 99(6): 2911-22.

[62] Sun, W. M., Xiao, T. F., Sun, M., Dong, Y. R., Ning, Z. P., Xiao, E., Tang, S., Li, J. W. (2015): Diversity of sediment microbial community in response to acid mine drainage pollution gradients in the Aha watershed (Southwest China). - Applied Environmental Microbiology, doi:10.1128/AEM.00935-15.

[63] Teng, W. K., Kuang, J. L., Luo, Z. H., Shu, W. S. (2017): Microbial diversity and community assembly across environmental gradients in acid mine drainage. - Minerals 7: 106.

[64] Tian, W., Zhao, Y., Sun, H., Bai, J., Wang, Y., Wu, C. (2014): The effect of irrigation with oil-polluted water on microbial communities in estuarine reed rhizosphere soils. - Ecology and Engineering 70: 275-281.

[65] USGS (2012): Coal-Mine-Drainage Projects in Pennsylvania. - Pennsylvania Water Science Center (Accessed 17 April 2012).

[66] Volant, A., Bruneel, O., Desoeuvre, A., Héry, M., Casiot, C., Bru, N., Delpoux, S., Fahy, A., Javerliat, F., Bouchez, O. (2014): Diversity and spatiotemporal dynamics of bacterial communities: physicochemical and other drivers along an acid mine drainage. - FEMS Microbiology and Ecology 90: 247-263.

[67] Wang, G. H., Liu, J. J., Qi, X. N., Jin, J., Wang, Y., Liu, X. B. (2008): Effects of fertilization on bacterial community structure and function in a black soil of Dehui region estimated by Biolog and PCR-DGGE methods. - Acta Ecology Sinica 28: 220-226.

[68] Wong, V. N. L., Dalal, R. C., Greene, R. S. B. (2009): Carbon dynamics of sodic and saline soils following gypsum and organic material additions: a laboratory incubation. - Applied Soilless Ecology 41: 29-40.

[69] Xu, W. H., Ge, Z. W., Poudel, D. R. (2015): Application and optimization of Biolog EcoPlates in functional diversity studies of soil microbial communities. - MATEC Web of Conference 22: 04015.

[70] Yaish, M. W., Al-Lawati, A., Jana, G. A., Patankar, H. V., Glick, B. R. (2016): Impact of soil salinity on the structure of the bacterial endophytic community identified from the roots of Caliph Medic (Medicago truncatula). - PLOS ONE 11(7): e0159007. 
[71] Yan, N., Marschner, P., Cao, W. H., Zuo, C. Q. (2015): Influence of salinity and water content on soil microorganisms. - International Soil Water Conservation Research 3: 316323.

[72] Yuan, B. C., Li, Z. Z., Liu, H., Gao, M., Zhang, Y. Y. (2007a): Microbial biomass and activity in salt affected soils under arid conditions. - Applied Soilless Ecology 35: 319328.

[73] Yuan, B. C., Xu, X. G., Li, Z. Z., Gao, T. P., Gao, M., Fan, X. W., Deng, H. M. (2007b): Microbial biomass and activity in alkalized magnesic soils under arid conditions. - Soilless Biology and Biochemistry 39: 3004-3013.

[74] Zahran, H. H., Moharram, A. M., Mohammad, H. A. (1992): Some ecological and physiological-studies on bacteria isolated from salt-affected soils of Egypt. - Journal of Basic Microbiology 32: 405-413.

[75] Zhang, H., Li, G., Song, X., Yang, D., Li, Y., Qiao, J., Zhang, J., Zhao, S. (2013): Changes in soil microbial functional diversity under different vegetation restoration patterns for Hulunbeier Sandy Land. - Acta Ecology Sinica 33: 38-44.

[76] Zhang, T. Y., Wu, Y-H., Zhuang, L. L., Wang, X. X., Hu, H. Y. (2014): Screening heterotrophic microalgal strains by using the Biolog method for biofuel production from organic wastewater. - Journal of Algal Research 6: 175-179. 